\title{
A Prospective Study of Knowledge and Perception towards the Efficacy of Anti-Aging Cosmetics among Female Population of Ras Al Khaimah, UAE
}

\author{
Fasiha Shah*, Omar Sarheed, K.V.R. Ramesh \\ Department of Pharmaceutics College of Pharmacy, RAK Medical \& Health Sciences University, Ras Al khaimah, UAE \\ Email:^fasiha@rakmhsu.ac.ae,sarheed@rakmhsu.ac.ae,venkat@rakmhsu.ac.ae
}

How to cite this paper: Shah, F., Sarheed, O. and Ramesh, K.V.R. (2017) A Prospective Study of Knowledge and Perception towards the Efficacy of Anti-Aging Cosmetics among Female Population of Ras Al Khaimah, UAE. Journal of Cosmetics, Dermatological Sciences and Applications, 7, 275-289.

https://doi.org/10.4236/jcdsa.2017.73025

Received: August 27, 2017

Accepted: September 26, 2017

Published: September 30, 2017

Copyright $\odot 2017$ by authors and Scientific Research Publishing Inc. This work is licensed under the Creative Commons Attribution International License (CC BY 4.0).

http://creativecommons.org/licenses/by/4.0/

\begin{abstract}
Introduction: Cosmeceutical is a term used to describe cosmetics with antiaging effects these days. The aim of the current study was to determine the efficacy of different type of antiaging dermatological products based on consumer self-assessment and to identify those driving factors that influence women's purchase of these products and to have an insight into their perception and knowledge about these products. Methods: A prospective study was conducted about the use of antiaging cosmetics, consumer satisfaction, skin concerns related with age, importance of younger looking skin and socioeconomic status. Results and Discussion: It was observed in the study that such products do work to improve skin conditions but the claim that wrinkles could be cured completely could not be determined. Participant reported discrepancies between ideal and real effect of antiaging cosmetics. Even if such cosmetic products are expensive people like to spend on these to fulfill the human dream of looking younger.
\end{abstract}

\section{Keywords}

Cosmeceutical, Wrinkles, Anti-Aging, Efficacy, Appearance, Skin Concerns

\section{Introduction}

Aging is an inherent continuous process that normally begins around 25 in the body.

Collagen production slows down and become cross linked and elastin has a bit less spring. Dead skin cells do not shed off and turnover of new skin cells decreases. This natural intrinsic process of aging is trigged with external factors 
like sun exposure, radiations and toxins, resulting in premature aging of our skin. Other external factors that will add to this premature ageing included our life style (no exercise, drinking or smoking), repetitive facial expressions, gravity and sleeping positions. All these factors together lead to changes in each skin layer which are unfortunately structural. Gradually skin looses elasticity, lines are wrinkles started to appear and skin is sagged.

Cosmeceuticals are cosmetic products with biologically active ingredients having drug-like benefits [1]. Cosmeceuticals are cosmetics products that are said to actually vanish wrinkles [2]. Dermatological research suggests that the bioactive ingredients used in cosmeceuticals do indeed have benefits beyond the traditional moisturizer [3]. "Renewing the skin's mattress is a key goal of cosmeceuticals" [4]. Cosmetic industry always makes claims about antiaging products that can do miracles. Serums, creams and lotions very appeal packed and cosmetic industries promoting their products using goddess looking models promising to erase the "very signs of aging" everything from "cellular renewal" and "DNA protection" to lists of complex chemical formulations [5]. Female population all over the world is exposed through media to an ideal image of beauty. Most of the products are applied locally for dermatological effects; these products contain ingredients which are naturally present in human skin during youth. That's why antiaging products contain mostly proteins, enzymes and substances which are either involved in the body for the production of new proteins or it can slow down the process of aging. Undoubtedly many of the ingredients have potent effects but comprehensive research on their effects is not available. "Even when rigorous studies are commissioned, companies usually control whether the work is published in the traditional scientific literature".

The objectives of this study were to:

1) Evaluate the efficacy of different types of antiaging cosmetics by self-evaluation of the participants before and after the use.

2) Knowledge and perception of women about antiaging products

3) Determine the driving factors that affect choices of antiaging cosmetics.

The antiaging movement is growing in nature that makes this topic very relevant in UAE where beauty sector is experiencing an extraordinary growth. Recent statistics reveals a growth of 12 per cent annually and market value of $\$ 1.7$ billion, which is expected to exceed $\$ 2.1$ billion this year [6]. It is estimated that Emirate women alone spend close to AED 1 billion (US \$272 million) per year on beauty products and treatments [7]. Working women with high disposable income spend more on cosmetics and beauty products and particularly on international brands, which are more popular in the UAE. According to Retail International, retail accommodation for beauty product retailers has grown $30 \%$ in the last three years to account for $25 \%-30 \%$ of all retail space in the UAE [8]. This rapid growth in cosmetics market in UAE has grabbed the attention of cosmetics companies internationally. The market's growth is also attributed to the region's demographics, with a population of young, fashionable trendsetters with high disposable income. According to the data provided by industrial 
technology Research Institute, as much as US dollar 0.1548 billion is worth the global cosmetics market in 2001, and the sum was expected to soar to US dollar 0.1817 billion in 2008 . One of the aims of this study was to determine the driving factors that influence women's decision to purchase antiaging cosmetics and the perception they have about these products. Previously many researchers have identified several factors that are important in the decision to have a cosmetic procedures. However, the role of these factors in the decision to purchase antiaging products has not been researched in Ras Al khaimah, UAE, hence, the project was conceived. Beauty image in media always equates with youth but this message has a disproportionate effect upon women where aging seems as a negative impact on female personality. Considering these factors the target population considered was females as majority of people who opt for cosmetic procedures and treatment are females as well. In addition, previously done marketing research published had revealed that women over the age of 50 are inclined to use antiaging products more [9] and women at younger age are very likely to purchase these products to stop the aging [10]. That is why the age for target population was considered 35 or above in the current study.

\section{Methods}

\subsection{Study Design}

The research study was a prospective cross-sectional survey. There were 13 closed end questions in the survey. These questions were related to demographic analysis, knowledge and perception, determination of various concerns about aging skin conditions, frequency of use and purchase of antiaging cosmetics, brand preferences, self-analysis of skin condition before and after using antiaging cosmetics and monthly expenditure on antiaging cosmetics and importance of appearance. Study design is summarized in Figure 1 as flow chart.

\subsection{Subjects}

Total of 100 subjects were planned to enrolled for data collection. Female population in Ras $\mathrm{Al}$ khaimah age above 35 years, should be using antiaging cosmetics for at least 2 months, randomly selected, were included. Subjects were required to sign an informed consent prior to study.

\subsection{Data Collection and Statistical Analysis}

Data collection and statistical analysis procedures included a questionnaire. The questionnaire was distributed manually and self-administered or the participant were interviewed. Data were tabulated in excel sheet and analyzed using SPSS 24-Data Analysis Software @ RAKMHSU Library after taking approval of ethical committee.

\subsection{Study Procedure and Assessments}

Each subject completed a questionnaire containing 13 questions evaluating 5 


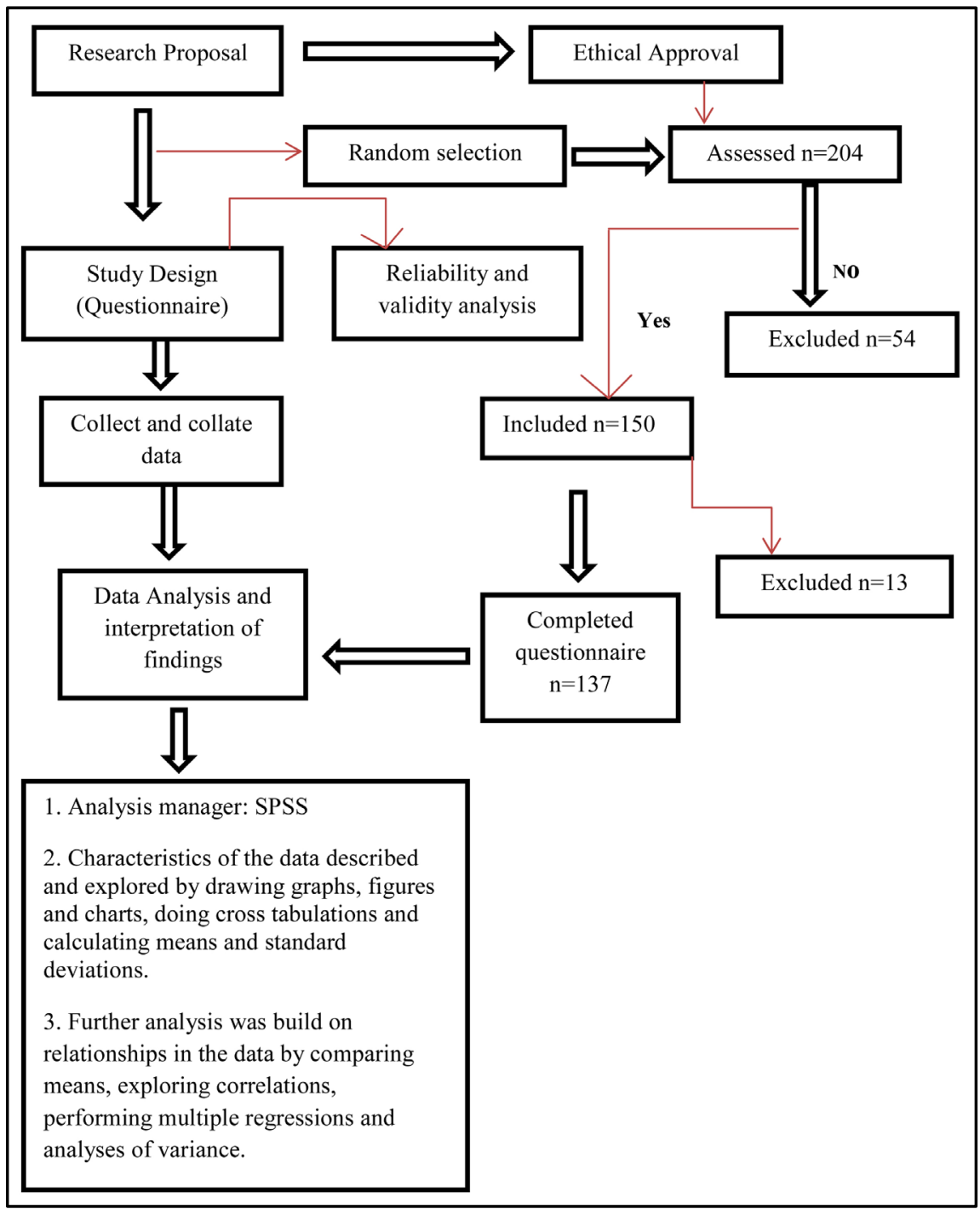

Figure 1. Flow chart of the study design.

efficacy attributes of antiaging cosmetics and driving factors to purchase antiaging cosmetics, main skin concern with age, duration of use and monthly income and expenditure on antiaging cosmetics. For self-evaluation of fine lines and wrinkles of antiaging cosmetics Fitzpatrick wrinkle scale (clinically validated and originally used for nasaolabial fold wrinkles) was used to quantify the depth of wrinkles while studying the antiaging effects [11] [12] [13]. This classification was comprised of three main classes of wrinkling represented as 1,2 and 3.5 indicating fine, moderate and deep wrinkles respectively (Table 1). A 0 is used in this classification to define absence of wrinkles. Furthermore, three main classes can be divided into interclasses as well to assess wrinkle severity (i.e., 0.5, 1.5 and 2.5). Other key antiaging parameters assessed were uneven skin tone( dark patches), firmness of the skin, skin hydration and visibility of pores. Scores to assess other parameters ranged from 0 to 4 for negligible, moderate and severe condition. All antiaging key parameters are summarized in Table 2. 
Table 1. Fitzpatrick scale of nasolabial folds used to determine the depth of finelines/wrinkles in the study.

\begin{tabular}{|c|c|c|c|}
\hline & Score & & Wrinkle Depth \\
\hline \multirow{6}{*}{ Class } & $0 \mathrm{~F}$ & No wrinkle. & - \\
\hline & $0.5 \mathrm{~F}$ & Very shallow yet visible wrinkle & - \\
\hline & I F & Fine wrinkle & $\begin{array}{l}\text { Visible wrinkle and } \\
\text { slight indentation }\end{array}$ \\
\hline & $1.5 \mathrm{~F}$ & Visible wrinkle and clear indentation. & 1-mm wrinkle depth \\
\hline & $2 \mathrm{~F}$ & $\begin{array}{c}\text { Moderate wrinkle } \\
\text { Clearly visible wrinkle }\end{array}$ & $\begin{array}{l}1 \text { - to } 2-\mathrm{mm} \\
\text { wrinkle depth }\end{array}$ \\
\hline & $2.5 \mathrm{~F}$ & Prominent and visible wrinkle & $\begin{array}{c}\text { More than } 2 \mathrm{~mm} \\
\text { wrinkle depth }\end{array}$ \\
\hline
\end{tabular}

Table 2. Key Parameters assessed for the efficacy of antiaging products.

\begin{tabular}{|c|c|c|c|c|}
\hline Parameter & Visible pores & Skin hydration & Skin laxity & $\begin{array}{c}\text { Evenness of skin } \\
\text { tone }\end{array}$ \\
\hline \multicolumn{5}{|l|}{ Score } \\
\hline 0 & Not visible & Very dry & Very loose & Very uneven tone \\
\hline 1 & Slight visible & Moderately dry & $\begin{array}{l}\text { Moderately } \\
\text { firm }\end{array}$ & $\begin{array}{c}\text { Moderately even } \\
\text { tone }\end{array}$ \\
\hline 2 & $\begin{array}{l}\text { Moderately } \\
\text { visible }\end{array}$ & Slightly moisturized & Slightly firm & Slightly even tone \\
\hline 3 & Obvious pores & Moderately dry & Firm & Even tone \\
\hline 4 & Maximum visible & Very moisturized & Very firm & Very even tone \\
\hline
\end{tabular}

\section{Results}

The survey was distributed randomly to about 207 females in total out of which only 150 were using any antiaging products and only 137 responses were considered to be included in the study. The rest of the 13 surveys were rejected due to fact that either were incomplete or incorrectly answered. Participants were asked a series of question about their age, their social economic status, race or ethnicity, nationality etc. Results are summarized in Table 1.

The participants age ranged between 35 to 60 years. Most of the respondents population consisted of Arabs and non-smoking (68\%) females. A small population seems to be familiar with the term "cosmeceutical" or the ingredients used in cosmeceuticals. Many had the believe that with longer use a better result is expected and a good number had shown a positive attitude to go for a cosmetic procedure if topical noninvasive treatment is not enough. Consumers choice indicates that quality is one of the main driving factor to choose a product. Price and brand name has a similar influence on the purchasing behavior. About 15\% of the participants were attracted by container shape and advertisements to purchase and $10 \%$ of the individuals will choose a specific product depending upon its availability in the market. $9 \%$ of the consumers were influenced by 
recommendations to purchase and only a small number of the population (4\%) seems to purchase a product depending upon its ingredients.

$33 \%$ of the population had a problem of fine line and wrinkles and $13 \%$ had rough and dry skin, $18 \%$ had a problem of open pores and $11 \%$ had age spots and $8 \%$ individuals had sagged skin. Importance of suppleness of skin was rated on a Licker scale starting from 5 indicates extremely important and ending at 1 indicating not at all important. Similarly, satisfaction level of the consumer was rated on a Lickert scale starting from 5 indicating extremely satisfied and ending at 1 indication not at all satisfied. Majority of the females agreed that skin is extremely important to them. As it can be seen that $23 \%$ of the respondents seems to be satisfied with product and $16 \%$ does not find the product useful at all (Figure 2). 22 candidates were using antiaging product for last 8 weeks only,19 participants for the last six months, 29 for one year and 32 for more than a year and 41 participants fall into the category for which the time of usage is even more than a year (Figure 3 ).

\section{Satisfaction Level of the Consumer}

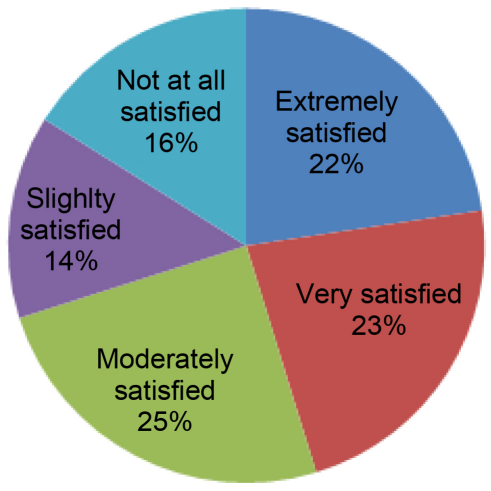

Figure 2. Satisfaction level of the consumer with antiaging product used.

\section{Duration of Use}

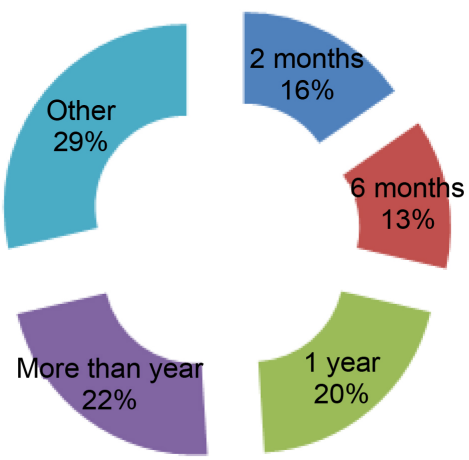

Figure 3. Duration of use of the participants of antiaging cosmetics. 
From the results it can be seen that women in UAE are really spending a lot of money on skin care cosmetics regardless of their earnings. Out of 137 female participants only $7 \%$ is spending less than 100 AED (Arab emirate dirham) on cosmetics and the highest number found to be $43 \%$ who are sparing more than 500 AED over cosmetics (Table 3). The last question in the survey was about the average monthly income. According to the percentage of this survey $46 \%$ of the participants are earning between 5000 to 10,000 AED with minimum salary status less than 5000 AED (12\%) and highest is $17 \%$ with more than 20,000 AED per month.

\section{Discussion}

The authors performed the SPSS statistics software for reliability analysis and verified the internal consistency with Cronbach's a value (0.05). The overall reliability achieved was 0.9065 (Table 4). Comparing the validity values obtained with a standard scale it was found that questions were valid (Table 5) and are able to measure what is desired [14].

Table 3. Age distribution of the participants and per month income in ${ }^{\star} \mathrm{AED}$ arranged as PIVOT table.

\begin{tabular}{ccccccc}
\hline Gender & Age Groups & $<5000$ AED & $\begin{array}{c}5-10,000 \\
\text { AED }\end{array}$ & $\begin{array}{c}10-20,000 \\
\text { AED }\end{array}$ & $>20,000$ AED & $\begin{array}{c}\text { Grand } \\
\text { Total }\end{array}$ \\
\hline \multirow{5}{*}{ Female } & $35-40 \mathrm{yr}$ & 13 & 19 & 11 & 4 & 47 \\
& $41-45 \mathrm{yr}$ & 1 & 18 & 13 & 1 & 33 \\
& $46-50 \mathrm{yr}$ & & 10 & 6 & 5 & 21 \\
& $51-55 \mathrm{yr}$ & & 8 & 8 & 2 & 18 \\
& $56-60 \mathrm{yr}$ & & & & 8 & 8 \\
\hline
\end{tabular}

*Arab emirates dirham.

Table 4. Reliability analysis of the questionnaire.

\begin{tabular}{ccc}
\hline Sr.No & Question & Alpha \\
\hline 1 & Importance of skin & 0.997 \\
2 & Satisfaction level of consumer & 0.997 \\
3 & Skin condition before the use & 0.855 \\
4 & Skin condition after the use & 0.825 \\
\hline
\end{tabular}

Table 5. Validty analysis of questionnaire.

\begin{tabular}{ccc}
\hline Validity coeffecient value & Interpretation & Determined value of validity \\
\hline 0.35 or above & Very beneficial & \\
$0.21-0.35$ & Likely to be useful & $0.385-0.387$ \\
$0.11-0.20$ & Depends & \\
Below 0.11 & Unlikely to be useful & \\
\hline
\end{tabular}

${ }^{*}$ Correlation is significant at the 0.01 level (2-tailed). 
The survey was distributed randomly to female population age 35 and above which were of different nationalities including Emarati, Syrian, Lebanese, Indian, Pakistani. Aljeerians, English etc but these females were divided into two group either local or expatriates and Arabs (74\%) and non-Arab. Majority of the participants were non-national 72 as compared to locals 65 (Table 6). Few questions of the survey were dedicated to determine knowledge, attitude and perception of women about the antiaging cosmetics. As from the results (Table 7) it can be seen out of 204 participants 150 said "yes" that they are using antiaging cosmetics. Only $12 \%$ of respondents were familiar with the scientific term "cosmeceutical" which is used to describe antiaging cosmetics these days. A very small number had knowledge or know the type of ingredients used in cosmeceuticals. $46 \%$ of the females were satisfied with the brand they are using, a high number (54\%) reported discrepancy with the outcomes of the product they are using. $72 \%$ of the participants agreed that with longer use of the preparation better results can be achieved.

As many participants have this belief using the product for longer time would yield a better result so we tested the hypothesis that longer duration means better improvement. The result of ANOVA test declared that the relationship between duration of use and improvement of skin condition is not significant (0.06). This result indicates that respondents with higher age are not satisfied with the effectiveness of the product no matter if they have been using it for long time. 56\% also agreed to change the brand if it is not working for them and $67 \%$ even considered going mile a head to opt for a cosmetics procedure other than the use of topical products to enhance their appearance. From these responses it can be suggested that generally people were not familiar or interested in the scientific terms used to describe the antiaging products they would rather remember the brand name than scientific terms which perhaps they find difficult

Table 6. Demographic parameters of participants summarized.

\begin{tabular}{ccccc}
\hline $\begin{array}{c}\text { Demographic } \\
\text { Parameters }\end{array}$ & $(\mathrm{n}=137) \mathrm{n}(\%)$ & $\begin{array}{c}\text { Demographic } \\
\text { Parameters }\end{array}$ & $(\mathrm{n}=137) \mathrm{n}(\%)$ & \\
\hline Gender & Female & Ethnicity & Arab & $74 \%$ \\
Non-Arab & $26 \%$ \\
Nationality & $37 \%$ & Smoking & $32 \%$ & \\
Local & $63 \%$ & Non smoking & $68 \%$ & \\
Expatriate & & Nationalities & & \\
Age in years & $37 \%$ & Syrian & $40 \%$ & \\
$35-40$ & $26 \%$ & Lebanese & $16 \%$ & \\
$41-45$ & $17 \%$ & Indian & $12 \%$ & \\
$46-50$ & $14 \%$ & Pakistani & $9 \%$ & \\
$51-55$ & $6 \%$ & Aljeerian & $18 \%$ & \\
$56-60$ & & English & $5 \%$ & \\
& & &
\end{tabular}


Table 7. Knowledge, attitude and perception of participants about antiaging cosmetics.

\begin{tabular}{|c|c|c|c|c|}
\hline & Question & Yes $\mathrm{n}(\%)$ & No $n(\%)$ & Total \\
\hline \multirow[t]{2}{*}{ Knowledge } & $\begin{array}{l}\text { Are you familiar with the term } \\
\text { "Cosmeceuticals". }\end{array}$ & $12 \%$ & $88 \%$ & 137 \\
\hline & $\begin{array}{l}\text { Do you know the type of ingredients } \\
\text { used in antiaging cosmetics? }\end{array}$ & $7 \%$ & $93 \%$ & 137 \\
\hline \multirow[t]{3}{*}{ Perception } & $\begin{array}{l}\text { Are you using any topical } \\
\text { preparation (cream, lotion) } \\
\text { for antiaging affect? }\end{array}$ & $150(74 \%)$ & $54(26 \%)$ & 204 \\
\hline & $\begin{array}{l}\text { Are you satisfied with the } \\
\text { brand you are using? }\end{array}$ & $46 \%$ & $54 \%$ & 137 \\
\hline & $\begin{array}{c}\text { Do you think long use of antiaging } \\
\text { cosmetics will result in } \\
\text { better outcomes? }\end{array}$ & $72 \%$ & $28 \%$ & 137 \\
\hline \multirow[t]{2}{*}{ Attitude } & $\begin{array}{l}\text { Have you considered changing the } \\
\text { brand you are using? }\end{array}$ & $(56 \%)$ & $(44 \%)$ & 137 \\
\hline & $\begin{array}{c}\text { Have you ever considered a cosmetic } \\
\text { procedure other than using topical } \\
\text { preparations? }\end{array}$ & $67 \%$ & $33 \%$ & 137 \\
\hline
\end{tabular}

to remember. Similarly, a very small number of population is interested to know what ingredients in the antiaging cosmetics had made a difference in the appearance. Their interest lies in the outcomes rather than how they achieved that outcome. $56 \%$ of the population is willing to change the brand for the desired outcomes. $44 \%$ showed no interest in changing the brand this behavior might be due to brand loyalty. People also believed that better results can be achieved with prolong use but in reality this does not happen for all.

According to Keller, "famous brand names disseminate product benefits and lead to higher recall of advertised benefits than non-famous brand names" [15]. There are many unfamiliar and alternative brands available in the market but consumers prefer to trust famous brands. The brand name and its image attract consumers to bring about repeat purchasing. It can be concluded from the result of the survey that consumers have a believe that brand name, price and quality are interrelated and they are willing to pay premium price for the brand they trust. Usually consumers think that high price means good quality. To analyze the relationship between these variables Pearson correlation was used. A moderate co-relationship $(r=0.429)$ was found between these three variables based on Cohen's guidelines [16]. Cosmetic industry spends millions of dollars on product advertisement taking the help of impressive channels available including TV, proactive press and electronic media. In our survey 40 females did choose their product under the influence of promotions and 30 bought the product once the packaging had inspired them. A positive relations $(0.001)$ has been observed between promotion of a product and expenditure. These results suggest that people are less sensitive to price and they would repurchase the product if they 
believe that high price is symbol of good quality. A very small percentage of population (4\%) did choose the product based on the ingredients which was an expected behaviour as lay man either are not interested nor very knowledgeable about the type of ingredients used for antiaging affects.

Over all result showed that women between the age 35 - 40 years are earning between 5000 - 20,000 AED per month and are spending between 250 to 500 AED per month only for antiaging cosmetics and treatments. It is interesting to note that, among our respondents, income was not hugely significant factor in indicating purchase of skin care cosmetics. Furthermore, the age distribution and income status is arranged in the form of PIVOT table (Table 2).

Wrinkles or fine lines is a skin condition commonly we associate with older age and was seemed to be a greater concern among the respondents. This concern, can be seen from results, is the same for all age groups. Age does not seem to be a significant factor for this skin concern. Age distribution and the skin concerns of respondents can be seen in Table 8. Is there any positive relationship between the age and satisfaction level of the consumer. The test analysis showed that there is a significant relation (0.000) between satisfaction level and consumer age which indicates that satisfaction level of the consumer decreased with increased age. Generally, it is considered that if the consumer is satisfied with the chosen product they would spend more. Or in other words we wanted to know is there any positive/significant relation between improvement of skin condition and expenditure? ANOVA result had shown a significant relationship between the two (0.000). Consumers like to spend on skin care products even if they are not satisfied. Because the key reason to consider the use of a cosmetics was the claim to maintain a youthful appearance even if the effectiveness of the product is questioned. This behavior demonstrates that those who feel that they have control over health will engage in more health related behaviours [17]. The feeling that they have control over aging process can explain why women will purchase antiaging cosmetics despite of questioning its effectiveness [18].

The participants assessed over all wrinkles on the face on a scale ranged from 0 to 3 indicating none, mild and severe wrinkles/fine lines. Before the use of antiaging cosmetics $1.4 \%$ had rated themselves at $0,16 \%$ had rated themselves at $0.5,21.1 \%$ at $1,18.2 \%$ at $1.5,15.3 \%$ at $2,13.1 \%$ at 2.5 and $14.5 \%$ at 3 respectively.

Table 8. Age distribution and Various skin concerns arranged as PIVOT table.

\begin{tabular}{cccccccccc}
\hline Gender & $\begin{array}{c}\text { Age } \\
\text { Groups } \\
\text { In years }\end{array}$ & $\begin{array}{c}\text { Fine lines/ } \\
\text { wrinkles }\end{array}$ & $\begin{array}{c}\text { Uneven } \\
\text { skin tone }\end{array}$ & $\begin{array}{c}\text { Age } \\
\text { spots }\end{array}$ & $\begin{array}{c}\text { Dark } \\
\text { patches }\end{array}$ & $\begin{array}{c}\text { Open } \\
\text { pores }\end{array}$ sagged Rough/dry & Grand \\
skin & Total \\
\hline & $35-40$ & 5 & 4 & 6 & & 4 & & & 19 \\
& $41-45$ & 8 & 3 & 7 & 8 & 6 & 3 & 2 & 37 \\
Female & $46-50$ & 11 & & & 5 & 8 & 5 & 3 & 32 \\
& $51-55$ & 15 & & 5 & 7 & 7 & 2 & 7 & 43 \\
& $56-60$ & 17 & & & 3 & 5 & 3 & 11 & 39 \\
\hline
\end{tabular}


After the use of antiaging products, 4 participants rated themselves at 0,22 at $0.5,27$ at 1,37 at 1.5, 11 at 2,9 at 2.5 and 19 at 3 of the wrinkle scale respectively (Figure 4). Out of 137 , only $35 \%$ participants had actually observed a visible change that is reduction of appearance of fine lines and wrinkles. Similarly, for pore visibility $67 \%$ had observed a reduction, for skin firmness $51 \%$ had felt an increase laxity of skin, 59\% had felt an increased skin hydration and $31 \%$ had seen homogenicity of skin tone (Figures 5-8).

The results for effectiveness of the products to reduce line and wrinkles were not found to be really consistent, although the shift of the subject self-evaluation score before and after the use from a higher level to lower severity can be consi-

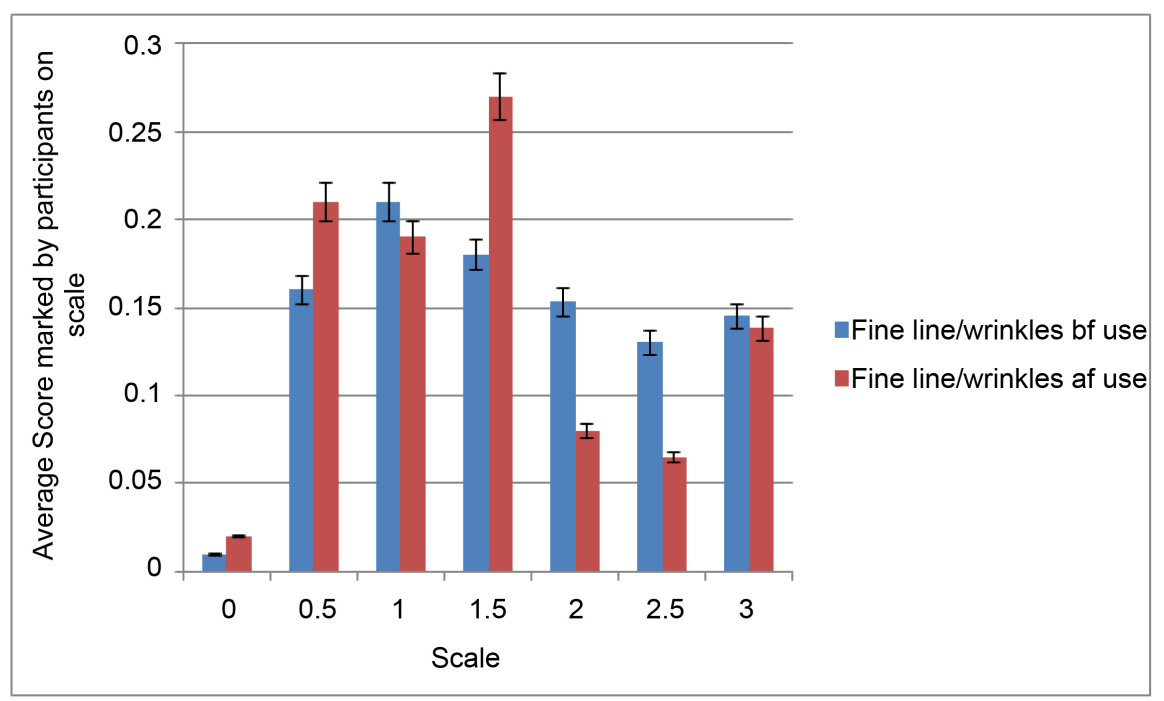

Figure 4. Self-analysis of fine line/wrinkles before and after the use. Average score marked by the subjects/Scale. Results were considered significant if $P<0.05$. Chi square test performed, results not significant $\mathrm{p}=0.007$. ${ }^{\star} \mathrm{bf}=$ Before, ${ }^{\star *} \mathrm{af}=$ after.

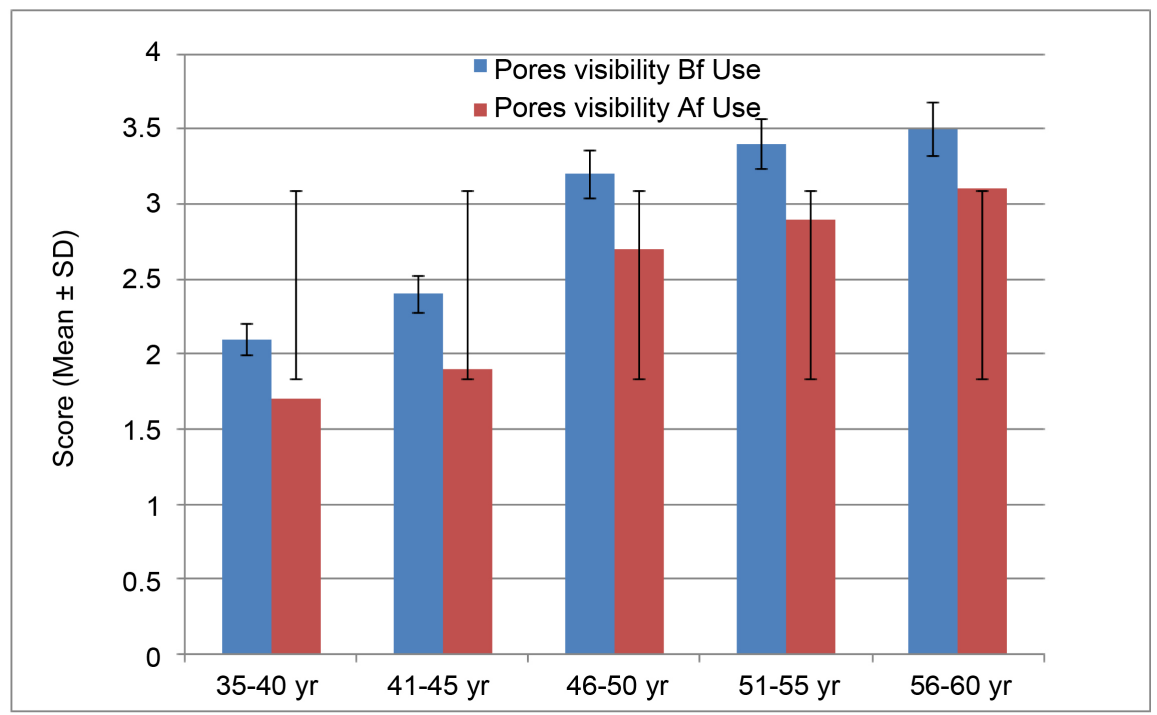

Figure 5. Visibility of pores. Self-assessment of pore visibility verses age groups before use and after use. 


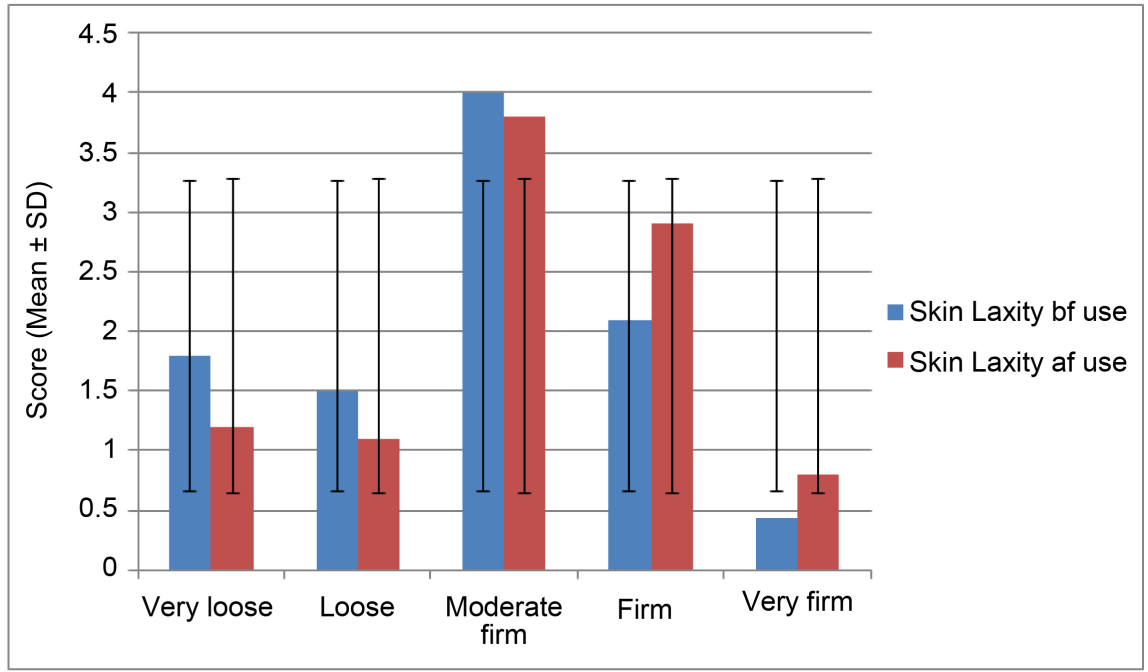

Figure 6. Self-assessment of skin laxity before and after the use of antiaging cosmetics.

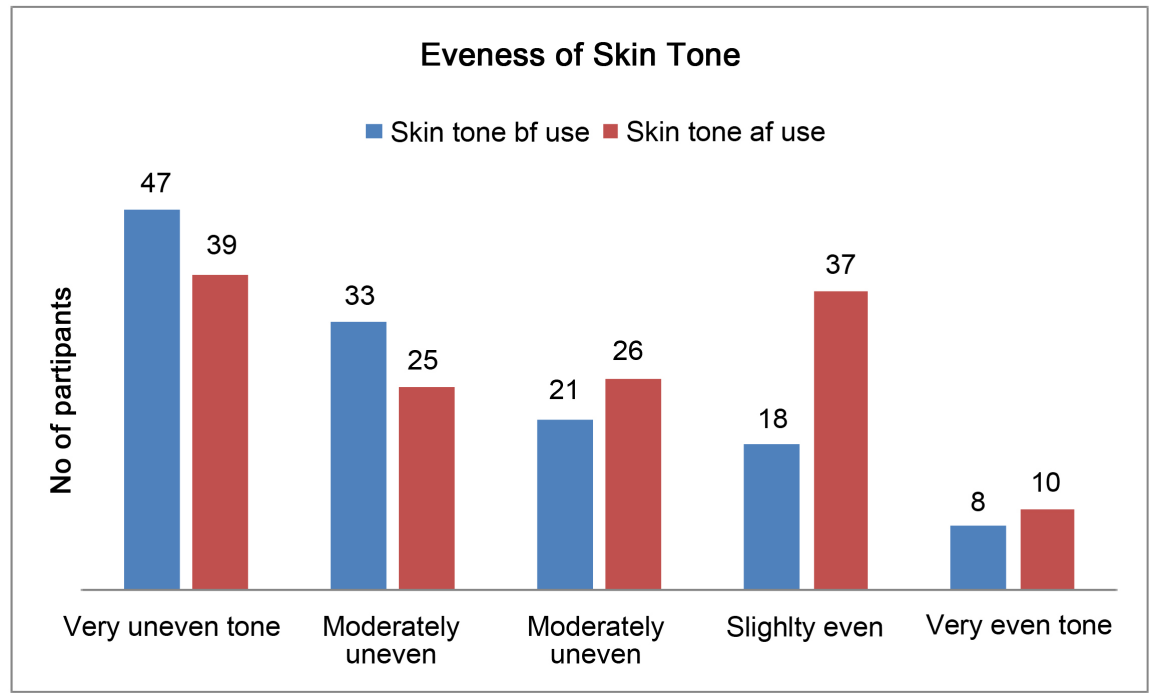

Figure 7. Self-assessment of Skin Tone before and after the use.

dered improvement but the effectiveness of even the best products was found to be limited and results seems to be varying from subject to subject. According to the participants some products did a visual change in wrinkle length or depth for at least few persons and did nothing for others. People did observe a reductions in wrinkle appearance, skin firmness and age spots severity and visibility of open pores the product worked best for slight type of wrinkles or for those who rated themselves on the lower side of the wrinkle scale, and nearly failed to do the "miracles that manufacturers seemed to imply on product labels". The results does not seem to be consistent because some participants were using these products for more than year but could not see the desired results while others who just used the product for 6 weeks and observed remarkable difference in the condition of their skin. A very likely explanation could be that the stratum corneum is impermeable to molecules with higher molecular weight and many 


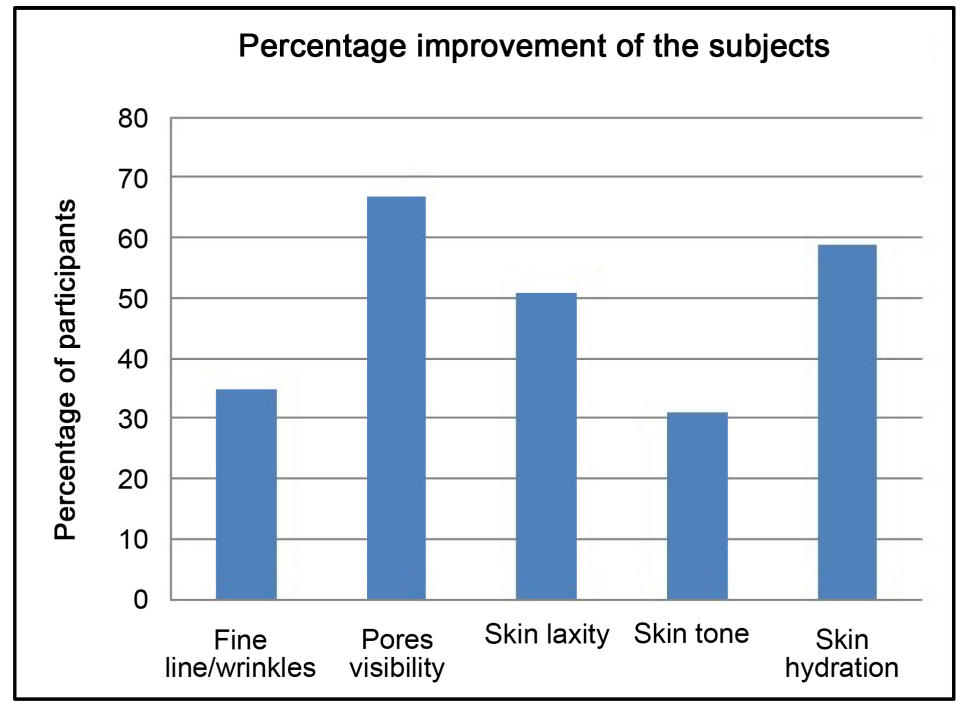

Figure 8. Proportion of improvement by subjects. Improvement of fine line/wrinkles was felt by $35 \%$; Reduction of pore visibility was felt by $67 \% ; 51 \%$ felt an increase laxity; Improvement of skin tone was felt by $31 \%$ and $59 \%$ felt an increase skin hydration.

ingredients used in antiaging cosmetics have a high molecular weight for example vitamin E [19]. From these results it can be seen that it is very likely that purchase of antiaging cosmetics may be related to consumer dissatisfaction with aging or psychological factors like change in physical appearance due to age. The change in physical appearance due to age causes anxiety which can act as a motivation to opt for cosmetic procedures. This can be observed from the result of this study as well that females inspite of questioning the effectiveness of the product seems willing to change the brand and consider other options as well. In addition, either using an antiaging cosmetics or a procedure like dermal fillers is an attempt to conceal or reverse the sign of aging and this trend can be seen in a large number of population whether smoking or nonsmoking, knowledgeable or not knowledgeable regardless of their ethnicity and nationality. People seems to believe that even the effectiveness is questioned they will use the product to lessen the appearance of line and wrinkles.

\section{Limitations}

1) The survey took a longer time than expected.

2) It was difficult to persuade people to fill the survey we found that people were hesitant to reveal their age or salary status.

3) There was no placebo group.

4) The results of the survey cannot be generalized.

\section{Conclusion}

The current study was a prospective cross-sectional survey. This project was conducted to determine the cosmetics purchasing needs, determine the efficacy 
of different products, and assess personal expenditure on these cosmetics and knowledge and perception about antiaging cosmetics of female population in Rasal khaimah, UAE. Generally, people are not familiar with term cosmeceuticals which is used to describe cosmetics which contain ingredients with antiaging effect. From the results of the survey it can be seen that the wild claims of beauty industry about their miraculous antiaging cosmetics like skin rejuvenation are not entirely true. In reality these products work for fewer people. No doubt people are able to see the difference before and after use but they could not achieve the desired results like banishing of wrinkles. Respondents had observed that their skin condition improved and it did not worsen with the continuous use but only fewer respondents had actually seen the disappearance of wrinkles or fine lines. Even though this does not change their belief about these products if they are not satisfied about one product they will simply change the brand but never stopped using. Consumers prefer quality products even if they are expensive and promotion does affect consumer's choice of the product. Females like to spend on skin cosmetics regardless of their income status. Fine line and wrinkles seems to be a major skin concern in all the age groups of participants.

\section{Acknowledgements}

Our sincere thanks to VC, Dean and RAK REC for their support and encouragement. I would like to acknowledge the efforts of Dr. Sarheed and Dr. Ramesh (chairperson) for the development of the survey questionnaire, for my support at every step and encouragement and Dr. Sarheed for statistical analysis and Arabic translation of the survey. Thank you to my dear students, Douha Shouqeer, Maha, Yaseen, who helped in conduction of survey and my colleagues who participated in the survey and gave valuable suggestions.

\section{References}

[1] Milam, E.C. and Rieder, E.A. (2016) An Approach to Cosmeceuticals. Journal of Drugs in Dermatology, 15, 452-456.

[2] Martin, K.I. and Glaser, D.A. (2011) Cosmeceutical the New Medicine of Beauty. PubMed, 108, 60-63.

[3] Chen, Z., Seo, J.Y., Kim, Y.K., Lee, S.R., Kim, K.H., Cho, K.H., et al. (2005) Heat Modulation of Tropoelastin, Fibrillin-1, and Matrix Metalloproteinase-12 in $\mathrm{Hu}$ man Skin in Vivo. Journal of Investigative Dermatology, 124, 70-78. https://doi.org/10.1111/j.0022-202X.2004.23550.x

[4] Grace R. Cosmeceuticals (2008) Functional Food for the Skin. Nat Foods Merchandiser.

[5] Roberts, M.S., Cross, S.E. and Pellett, M.A. (2002) Skin transport. In: Walters, K.A., Ed., Dermatological and Transdermal Formulations, 89-195. https://doi.org/10.1201/9780824743239.ch4

[6] Chaudhry, M.D. (2008) Cosmetic Industry Achieves Big Growth in the Region. Khaleej Times, 22 April 2008.

[7] Mena Report (2009) 
[8] Abed Al Aziz, N. (2006) Appearance Value in the Midddle East. TDC Trade. www.tdctrade.com/imn/06051603/cosmetic033.htm

[9] Capitalizing on the Cosmeceutical Market (2007) Inside Cosmeceuticals.

[10] Katsigiannis, J. (2005) Age Worries Starting Younger. Calgary Herald, C18.

[11] Shoshan, M.D., et al. (2008) The Modified Fitzpatrick Wrinkle Scale: A Clinical Validated Measurement Tool for Nasolabial Wrinkle Severity Assessment. Dermatologic Surgeon, 34, S85-S91. https://doi.org/10.1097/00042728-200806001-00018

[12] Lemperle, G., Holmes, R.E., Cohen, S.R. and Lemperle, S.M. (2001) A Classification of Facial Wrinkles. Plastic and Reconstructive Surgery, 108, 1735-2001. https://doi.org/10.1097/00006534-200111000-00048

[13] Day, D.J., Littler, C.M., Swift, R.W. and Gottlieb, S. (2004) The Wrinkle Severity Rating Scale: A Validation Study. American Journal of Clinical Dermatology, 5, 49-52. https://doi.org/10.2165/00128071-200405010-00007

[14] Chapter 3: Understanding Test Quality-Concepts of Reliability and Validity. http://www.hr-guide.com/data/G362.htm

[15] Keller, K.L. (2003) Strategic Brand Management: Building, Measuring and Managing Brand Equity. Prentice Hall, Upper Saddle River.

[16] Cohen, J. (1988) Statistical Power Analysis for the Behavioral Sciences. 2nd Edition, Lawrence Erlbaum.

[17] Muise, A. and Desmarias, S. (2010) Women's Perceptions and Use of "Anti-Aging” Products. Sex Roles, A Journal of Research, 63, 126-137. https://doi.org/10.1007/s11199-010-9791-5

[18] Norman, P., Bennett, P., Amith, C. and Murphay, S. (1998) Health Focus of Control and Health Behavior. Journal of Health Psychology, 3, 171-180. https://doi.org/10.1177/135910539800300202

[19] Andrews, S.N., Jeong, E. and Prausnitz, M.R. (2013) Transdermal Delivery of Molecules Is Limited by Full Epidermis. Not Just Stratum Corneum. Pharmaceutica Research, 30, 1099-1109.

\section{Submit or recommend next manuscript to SCIRP and we will provide best service for you:}

Accepting pre-submission inquiries through Email, Facebook, LinkedIn, Twitter, etc. A wide selection of journals (inclusive of 9 subjects, more than 200 journals)

Providing 24-hour high-quality service

User-friendly online submission system

Fair and swift peer-review system

Efficient typesetting and proofreading procedure

Display of the result of downloads and visits, as well as the number of cited articles

Maximum dissemination of your research work

Submit your manuscript at: http://papersubmission.scirp.org/

Or contact jcdsa@scirp.org 